\title{
A Comparative Study of Approaches to Teaching French and English for Future Specialists in Mining Industry
}

\author{
Marina Ryabova ${ }^{1}$, and Tatyana Sergeychick ${ }^{1, *}$ \\ ${ }^{1}$ Kemerovo State University, Institute of Philology, Foreign Languages and Mediacommunications, \\ Department of Foreign Languages, 650000, 6 Krasnaya st., Kemerovo, Russia
}

\begin{abstract}
The article highlights the specific features of the foreignlanguage instruction in the system of higher education in Russia. The principles of teaching French for future specialists in mining industry of Kuzbass in comparison with that of English in the institutions of higher education are analyzed. The focus is on the actual difference of approaches to teaching French and English at universities from the standpoint of the student/teacher ratio, basic principles of language education and its content. The variety of extracurricular activities at Kemerovo universities is described as a solution to the current problems in teaching French. The contribution of Language and Culture Centers at Kemerovo State University to training specialists for coal-mining enterprises of Kuzbass is revealed.
\end{abstract}

\section{Introduction}

Professional training of specialists for the coal-mining industry in Kuzbass began in 1950s - with the need to carry out the new tasks such as development of coal preparation technologies, advance in exploitation of coal deposits, environment protection, occupational safety and others. The study of a second (foreign) language has always been a compulsory part of the universities' academic programs. So, «Foreign Language» as a general subject has always been included in the list of basic disciplines at higher educational institutions in Russia.

The university course of foreign language at non-linguistic departments presents in itself a multi-faceted and complex educational product based on didactic principles and professional character of the content. The university course of a foreign language presupposes the mastering linguistic competences in connection with the process of developing intellectual, educational and professional culture of a specialist. This ensures the proficiency of future engineers, economists, exploration geologists, environmental managers etc. for coalmining enterprises in Kuzbass region.

\section{Materials and methods}

\footnotetext{
* Corresponding author: lalli8@,mail.ru
} 
The research presents the experience of teaching foreign languages for the future specialists in mining industry in the system of Russian higher education.

In preparing the article the following methods and materials were used: reviews of publications on the problems of teaching French and English at higher educational institutions; interviews with teachers of foreign languages (68 interviewees) and students (300 interviewees) at Kuzbass universities (Kuzbass State Technical University, Kemerovo State University (Kemerovo); analyzing the practice of teaching English at Kemerovo universities; survey of the experience in managing the Department of Foreign Languages, analyzing qualitative data on academic hours allotted to studying/teaching foreign languages; evaluation of the content of language education for French and English at universities.

\section{Results and discussion}

To compare the status of the French language with that of English in the modern educational process at universities of Kuzbass region, it is crucial to describe some general features of the system of foreign-language instruction in Russia.

At schools pupils can usually choose one of three foreign languages: English, German or French. In universities they traditionally continue to learn the same foreign language they had at school.

From 1960s to 1980s the amount of academic hours for foreign-language instruction was considerable at Kuzbass universities. The reason was the Resolution "On the improvement of foreign language learning" made by the Council of Ministers in the USSR in 1961. At universities a foreign language was taught for three or four years (7-8 semesters) in academic programs for non-linguistic specialties. Teaching foreign languages in classrooms had been a priority (4 lessons a week) for a long time, which was natural enough because linguistic competences can be mastered in a process of immediate live communication.

In 1992 the system of university education in Russia was radically changed because of its transition into a two level system and the standardization of education. The adoption of the law "On education" in 1992 and "On university and post-university education" in 1996 led to the increase in total number of academic hours for foreign-language instruction, but the decrease in hours for classroom teaching at the same time. Since then foreign language at universities had been taught only during 4-5 semesters ( 1 or 2 lessons a week) or 340 hours for the whole course. Nevertheless, the new requirements for the course of foreign language at universities had been considered as adequate.

Since 2003 the system of university education in Russia has been developing in accordance with Bologna declaration. The principles for foreign language education were formulated in the "Model program for foreign-language instruction at non-linguistic institutions of higher education" by professor S. Ter-Minasova in 2009. The focus on Language for Special Purposes has become a basic approach in defining the content of language education [10]. In 2011 a two-level system of higher education was eventually adopted in Russia, i.e. bachelor's degree course (baccalaureate) (4 years) and master's degree course (2 years).

In the majority of cases this transition was accompanied by the radical reduction of academic hours for foreign-language instruction. The decisive factor in this process was the attitude of a faculty's administration to allotting hours to foreign language as a subject. Total hours for foreign-language instruction as well as hours for classroom teaching started to vary greatly at different departments. Thus, for some departments at Kemerovo State University the total/classroom hours ratio remained more or less adequate: for example, 360/180 h at the Department of Chemistry, 252/168 h at the Department of Physics; while for other departments it was less than enough, for instance, 252/109 $\mathrm{h}$ at the Department of Economics, $72 / 36 \mathrm{~h}$ at the Department of Law. 
As for the programs of study leading to master's degree which have been available for over 4-5 years on the average at Kemerovo universities, there is no consistent approach to the amount of academic hours for foreign-language instruction as well as to its content. The hours for the foreign language as a subject at Kemerovo State University vary from 108/20 hours at the Department of Economics to 144/42 hours at the Department of Geography and Geology. Moreover, the Department of Law tends to exclude entirely the subject from their curriculum, which contradicts the official standards of higher education.

Thus, characterizing in general the foreign language education at non-linguistic departments of Kemerovo universities it is necessary to note the lack of uniform approach to organizing the process, resulting in a flexibility of total academic hours, persistent attempts to change the content and concept of the program, which is a reaction towards the changes in educational standards enacted by the Ministry of Education and Science in Russia.

Speaking about the popularity of foreign languages themselves, it was always different. In 1960s-1980s French as a foreign language was chosen often enough by the students at secondary school. Since 1960s the popularity of English in the world has begun to increase. The process was evidently the result of the USA domination in economic, political and cultural life. For a time the spread of English did not influence Kemerovo universities, since Kuzbass is rather far from the center of Russia. So, before 2000s each non-linguistic department of a Kuzbass university managed to form adequate academic groups of 10-15 students learning French as their foreign language. Though it is necessary to remind that the population in Russia of the period from 1989 to 2002 diminished for about 1.8 million people, consequently the number of school graduates as potential students naturally had become less since $2005[6,11]$. The phenomenon is known as "demographic gap".

As a result, since 2000 s there has been a tendency to form the so called "mixed groups" for French studies consisting of students of different departments. This conditioned more difficulties for a university teacher to organize teaching French in such groups [2]. The choice of a didactic material with professional orientation has become individual - for every student, in accord with his/her field of study.

In 2000 - 2010 the number of students learning French diminished drastically. Just two separate groups of about 10 students (for humanitarian and natural sciences) were formed to learn French. It was more problematic for a teacher of French to find a common methodical material for mixed groups of students of some unrelated fields (for example, chemistry and programming) which could be more or less convenient.

During the last decade the number of students learning French at a bachelor's degree level has diminished critically: there are only about 10 students of the total student population of over 5000 at Kemerovo State University. It becomes more obvious that groups of students learning English outnumber the ones learning French. The matter has been escalated by the strict requirement from the Ministry of Education and Science to a student/teacher ratio in Russian universities [7]. So, the university administration strongly recommended to form one single group for students of all departments to study French.

Thus, mastering professional competences through teaching foreign language for special purposes has been ignored in such mixed groups for French studies. A teacher has to organize the course of French in three training modules: French for general purposes, French for academic purposes, business French and national studies. Students are to master special professional vocabulary independently through reading original books instead of classroom work with a teacher face-to-face [8].

Regarding the methodical aspects of French language teaching it is important to mention that there is a consistent trend towards a significant decrease in a variety of textbooks of French for undergraduate students of non-linguistic fields. However, we must acknowledge the good quality of these scarce textbooks, and note their relevance to the educational standards in Russia. 
There is a gaping lack of textbooks of French for graduate students, as they are very difficult to get, often written in other institution, primarily for internal use. To solve the methodological problems teachers of French are to search for specific original texts written in French or to adapt the appropriate French articles in the scientific journals - which are not abundant themselves.

Describing positive aspects of language teaching at the university it is necessary to admit that for the last 5-7 years the administration of Kemerovo State University has substantially enlarged the availability of personal computers along with computer laboratories and multimedia facilities for students. This, to a large extent, contributes to improving the foreign-language instruction $[1,3,5]$, including French studies. Now a teacher of French can afford to organize students' individual work with professional content in class.

The daily matters of French language studies are getting more complicated and inconvenient, because it is nearly impossible to make out an adequate timetable for mixed groups: full-time students have to attend French classes at odd time. But the most difficult is to organize the work of part-time students: their curricula, timetables and schedules for end-of-term examinations differ in dates and duration. So, it is absolutely impossible to unite these students learning French in one group. Instead of giving lessons, a teacher of French in fact provides individual tutorials to every part-time student of different departments.

The same happens with graduate students learning French. In addition to asynchrony in the process of studies, low attendance rate among students of master's degree programs is also a problem (because of their day-time employment or having a child). The seminar classes are properly held due to motivating behavior of the teacher [4]. But, teaching French in "mixed" groups inevitably violates the principle of teaching language for specific purposes, which is vital at this stage of education [9].

The problems of French-language instruction at Kemerovo State University have been undoubtedly conspicuous to administration. The Department of Chemistry was the first to respond to them: the Head decided to form a mixed group of students who studied French and German at school, plus students with the lowest grade for English, into a group for studying English as beginners. Then this method has been adopted by the other departments of the Institute of Fundamental Sciences. So, the English language groups for beginners have become adequate as they counted to twenty students.

To reduce the degradation process in the field of French studies in university education, an initiative of the Embassy of France in Russia in 2003 to establish the Regional French Language and Culture Resource Center was supported by the administration of Kemerovo State University. The activities of the Resource Center were organized by the Department of French Philology of the university. Kemerovo State University is one of twenty-two educational institutions in Russia having the French Language and Culture Resource Center. The main objective of this Resource Center is to hold the ground for French studies in the entire Russian Federation and Kemerovo region in particular.

The French Language Resource Center at Kemerovo State University provides students and teachers, as well as all citizens of Kemerovo region, with an access to the French culture, an insight into the French language and the knowledge of admission policies and terms of educational opportunities in France. The resource center shares the new advanced methods of teaching language developed by French scholars which are of interest to school teachers. Guests and visitors of the Resource Center have access to a wide range of printed language material: original and adapted literature in French, numerous French periodicals, reference books and dictionaries, course books and scientific editions, authentic audio and video records for extracurricular activities and independent work.

The task of the Resource Center is to extend opportunities for students and teachers to study in France - through exchange trips, internship etc. The Center itself provides courses 
of French at different levels: courses for adults and children, seminars for teachers, it organizes summer language camps for various target groups.

Besides, the language proficiency Certification center was founded inside the Resource Center. The Certification center provides examination sessions and testing for diploma certifying knowledge of French as a foreign language (DALF/TCF), as well as professional French language skills (CCIP). The opportunities for individual portfolio of language skills are provided by preparing students for DELF-DALF, TEF, and TCF examinations under the Embassy of France in Russia.

The French Language and Culture Resource Center at Kemerovo State University helps to overcome the above-mentioned negative factors in teaching French by means of tremendous range of extracurricular activities. It arranges cultural and public events for a wide audience, which are dedicated to the French language and traditions of French-speaking nations. The most remarkable among them is the annual transregional French song festival "Etoile", organized by the Resource Center since 2004, which is held in the concert hall of Kemerovo State University. The festival unites people aged $18-35$ years who love the French language and songs in French. Its jury panel usually consists of a native speaker, a musician, a choreographer or an actor, a teacher of French, a representative of the university administration.

Another way to support French at the university is the annual (since 2003) week of European Languages. This is the sequence of events dedicated to languages, history and culture of European countries. The week of European Languages is usually held at the end of September coinciding with the European Day of Languages, celebrated on September 26.

The week of European Languages is organized by the Institute of Philology, Foreign Languages and Media Communications. Everyone interested in languages is invited. There is a traditional competition of posters in French along with presentations on particular subjects (e. g. "French comedians as generation icons"). The Department of French Philology organized numerous cultural events in the French language such as the Evening With a Song called "Venez chantez en Français, en Italien et en Espagnol!" Besides, it was arranged that a university cafe served French cuisine during the day, as well as held an entertainment game "Concours Culinaire Français" for students.

During the week of European Languages in order to promote the knowledge of the French language and culture teachers organize student leisure in Ciné-club (Cinema Club) demonstrating films in French in a university theater.

Lately, in addition to the above mentioned ambitious projects held by the Resource Center, there has been an acceptable practice to organize the public dictation for the French language lovers to check their literacy.

Thus, the activity of the French language and culture resource center contributes to the language education not only in Kemerovo State University but the whole Kemerovo region as well.

As for English language teaching at Kuzbass universities for the future specialists in mining industry, the situation is comparatively positive from different points of view. The groups of students learning English have always been adequate in number regarding the student/teacher ratio. The variety of textbooks of English for university students of different fields is good enough to organize properly the process of teaching language for specific purposes. Moreover, teachers of English are able to make use of numerous publications in scientific journals focused on different aspects of coal-mining. So, there are no methodical difficulties in choosing the content for in-class studies as well as for independent learning.

On the other hand, the extracurricular activities in Kemerovo university are not as various and intensive as those for French. Using the positive experience of the Regional French Language and Culture Resource Center, the English Language and Culture Centre (ELACC) was established in January 2017. The number of activities at present includes 
organizing scientific seminars and language events (like public dictation), providing Christmas lectures on linguistics for students. Its goals are not primarily to support English itself but to develop the international links and contacts in the spheres of science, education and culture thus encouraging and facilitating occupational mobility of Kuzbass students.

\section{Conclusion}

The English language for more than twenty years has had dominating position among foreign languages in the number of students in Kuzbass institutions of higher education. The reason is the actual world leadership of the United States of America in the political, economic, and cultural spheres. Now students actually do not have an alternative to English as a foreign language to learn at school, and then at university. So, the number of learners of French and German at Kemerovo State University reduced to less than 5\% of the total student population with the constant downward trend.

In the last ten years Kemerovo State University is gradually refusing teaching French as a subject for future specialists of coal-mining industry offering the English for beginners instead. The main factor of that is the small number of students learning French: groups consisting less than 12-15 people make up a bad student/teacher ratio at a university. As a result there have been some negative phenomena in teaching French in Kuzbass universities such as mixed groups of students, lack of textbooks of French for the future specialists in mining industry, difficulty for a teacher to choose the content for current lessons and independent studies in respect of teaching French for special purposes.

To support teaching and learning French, the Regional French Language and Culture Resource Center at Kemerovo State University organizes various cultural, educational and scientific events. The future specialists of coal-mining industry who learn French are able to take part in a lot of activities organized by the Center - courses, scientific seminars and conferences, different language festivals, games and competitions. Kuzbass learners of French can use special dictionaries and literature. In addition to extracurricular activities that are aimed to improve students' language skills, the French Language and Culture Resource Center provides services of certifying knowledge of French as a foreign language.

The English language teaching for future specialists in coal-mining has been successful for the whole period of its dominance. The groups of students learning English in Kuzbass universities are characterized by a better student/teacher ratio. The textbooks of English are various and abundant: there is an adequate methodological basis to organize teaching English for special purposes at Kemerovo universities. As for curricula, the departments of natural science allot enough hours to teaching English. So, for a long time it was not necessary to enlarge the range of extracurricular activities connected with the English language. But, taking into consideration the success of the Regional French Language and Culture Resource Center, the similar center for English was established at Kemerovo State University. They have different tasks: the English Language and Culture Centre (ELACC) aims to fix the international links in the spheres of science, education and culture thus encouraging and facilitating occupational mobility for the future specialists in coal-mining.

\section{References}

1. A. Armellini, B.C.P. Rodriguez, J. Interact. Online Learn.,14:1, 17-28 (2016)

2. E. Bondareva, G. Chistyakova, Yu. Kleshevskyi, S. Sergeev, A. Stepanov, E3S Web of Conferences, 21, 04019 (2017)

3. T. Deveci, New Horizons in Adult Education and Human Research Development, 21:3/4, 16-28 (2017) 
4. O. Greenwald, R. Islamov, T. Sergeychick, E3S Web of Conferences, 21, 04012 (2017)

5. M. S. Knowles, E. F. Holton, R. A. Swanson, The Adult Learner: The Definitive Classic in Adult Education and Human Resource Development. (Elsevier Butterworth Heineman, London-New York, 2005)

6. T. Leshukov, O. Brel, A. Zaytseva, Ph. Kaizer, K. Makarov, E3S Web of Conferences, 21, 4026 (2017)

7. O. E. Malikh, I. K. Polyanskaya, M. E. Konovalova, O. Y. Kuzmina, O. V. Tarasyuk, I. V. Osipova, IEJME: Math Educ., 11:8, 3104-3113 (2016)

8. R. Nunn, C. Brandt, T. Deveci, Asian ESP J., 12:2, 9-53 (2016)

9. F. Ozturk, T. Deveci, E. Gunister, R. J. Simmons, Innovative instructional strategies for teaching materials science in engineering (Materials Science and Engineering, London, 2017)

10. S. G. Ter-Minasova, World Englishes, 24:4, 445-454 (2005)

11. H. Wang, L. Dwyer-Lindgren, K. T. Lofgren, J. K. Rajaratnam, J.R. Marcus, A. LevinRector, C. E. Levitz, C. J. L. Murray, A. D. Lopez, The Lancet, 380:9859, 2071-2094 (2012) 